\title{
Retinal Detachment and Defect
}

National Cancer Institute

\section{Source}

National Cancer Institute. Retinal Detachment and Defect. NCI Thesaurus. Code C26967.

An imperfection if the retina of the eye in association with detachment of the retina from its blood supply. 